\title{
Fast ice distribution in Adélie Land, East Antarctica: interannual variability and implications for emperor penguins Aptenodytes forsteri
}

\author{
Robert A. Massom ${ }^{1,2, *}$, Katrina Hill ${ }^{3}$, Christophe Barbraud ${ }^{4}$, Neil Adams ${ }^{2,5}$, \\ André Ancel ${ }^{6}$, Louise Emmerson ${ }^{1}$, Michael J. Pook ${ }^{7}$ \\ ${ }^{1}$ Australian Antarctic Division, Department of the Environment, Water, Heritage and the Arts, Channel Highway, Kingston, \\ Tasmania 7050, Australia \\ ${ }^{2}$ Antarctic Climate and Ecosystems Cooperative Research Centre, Private Bag 80, c/o University of Tasmania, Hobart, \\ Tasmania 7001, Australia \\ ${ }^{3}$ Institute of Antarctic and Southern Ocean Studies (IASOS), Private Bag 77, c/o University of Tasmania, Hobart \\ Tasmania 7001, Australia \\ ${ }^{4}$ Centre d'Études Biologiques de Chizé, CNRS UPR 1934, 79360 Villiers en Bois, France \\ ${ }^{5}$ Australian Bureau of Meteorology, GPO Box 727 Hobart, Tasmania 7001, Australia \\ ${ }^{6}$ Institut Pluridisciplinaire Hubert Curien, Département Ecologie, Physiologie et Ethologie UMR 7178 CNRS-ULP, \\ 23 Rue Becquerel, 67087 Strasbourg Cedex 02, France \\ ${ }^{7}$ CSIRO Marine and Atmospheric Research, GPO Box 1538, Hobart, Tasmania 7001, Australia
}

\begin{abstract}
Antarctic fast ice is of key climatic and ecological importance, yet its distribution and variability are poorly understood. We present a detailed analysis of fast ice along the Adélie Land coast (East Antarctica) using satellite data from 1992 to 1999. Fast ice formation along this coastline is intimately linked to grounded iceberg distribution in waters of $<350 \mathrm{~m}$ depth. Considerable interannual variability occurs in areal extent and formation/break-up; the variability is related to wind direction. Distance to the fast ice edge and its extent are major determinants of emperor penguin Aptenodytes forsteri breeding success at Pointe Géologie. Of crucial importance are the frequency and duration of fast ice break-out events in the deep-water trough north-northwest of the colony. Successful penguin breeding seasons in 1993, 1998 and 1999 ([number of fledged chicks in late November / number of breeding pairs] $>75 \%$ success) coincided with lower-than-average fast ice extents and persistently short distances to nearest open water (foraging grounds), and corresponded to a strong positive phase of the Southern Annular Mode. Poor breeding seasons in 1992, 1994 and 1995 (success <15\%) coincided with average to slightly higher-than-average ice extents and persistently long distances to foraging grounds. Poor-to-moderate breeding years (success 40 to 50 \%), e.g. 1996 and 1997, occurred with above-average ice extents combined with fairly long distances from breeding to foraging grounds during the chick nurturing season. The overall correlation between breeding success and distance was high $\left(r^{2}=0.89\right)$, albeit based on a limited number of years $(n=8)$. Substantially less fast ice was present in two Argon satellite photographs taken in August and October 1963. This coincided with a highly successful breeding season and appears to have been related to stronger and more southerly winds.
\end{abstract}

KEY WORDS: Antarctic fast ice · Emperor penguin · Breeding success · Pointe Géologie · Wind · Interannual variability

Resale or republication not permitted without written consent of the publisher

\section{INTRODUCTION}

Fast ice is sea ice that forms and remains fast (or fixed) to the shore, an ice front, or grounded icebergs (WMO 1970), in contrast to pack ice, which is con- stantly in motion in response to ocean currents, winds and other forces. A key feature of fast ice is its recurrence and persistence in certain locations. It forms a highly compact ice cover that can be either annual or perennial, the latter occurring in more sheltered loca- 
tions (Giles et al. 2008). Ephemeral breakouts do occur during storms (Heil 2006), while break-up by oceanswell penetration becomes a factor later in the season when the protective surrounding pack ice has dispersed (Crocker \& Wadhams 1989, Langhorne et al. 2001, Ushio 2006).

While Antarctic pack ice extent and its global climate ramifications have been the focal point of significant recent research and concern (see Lubin \& Massom 2006 for a summary), relatively little is known about Antarctic fast ice distribution, its seasonal/interannual/long-term variability and factors affecting this variability or its ecological impact. Fast ice has been monitored at a limited number of sites or areas using in situ, aircraft and satellite observations, e.g. Yamanouchi \& Seko (1992), Murphy et al. (1995), Enomoto et al. (2002), Heil (2006), Ushio (2006). Wider-scale studies were carried out by Kozlovsky et al. (1977, cited in Fedotov et al. 1998), and Giles et al. (2008), but are limited in their temporal coverage and do not reveal the frequency and extent of break-up and formation episodes.

Although fast ice forms only a small proportion (an estimated $4 \%$ ) of the total area of the Antarctic sea ice zone at maximum extent each September-October (Kozlovsky et al. 1977, cited in Fedotov et al. 1998), it constitutes a pre-eminent feature of the coastal zone. Responding rapidly to atmospheric and oceanic forcing, it is a sensitive indicator of climate change and/or variability (Murphy et al. 1995, Heil 2006). As it can attain a considerable thickness ( $>5 \mathrm{~m}$ for perennial fast ice, Massom et al. 2001), it likely comprises a substantial proportion of the total Antarctic sea ice volume (Giles et al. 2008) and forms an important component of the ocean freshwater budget. Moreover, fast ice is of critical ecological importance as a key habitat for microorganisms (Garrison 1991), a region of enhanced primary productivity (Satoh \& Watanabe 1988, Arrigo et al. 1993, McMinn et al. 2000) and a breeding platform for Weddell seals Leptonychotes weddelli (Thomas \& DeMaster 1983) and emperor penguins (Kirkwood \& Robertson 1997a, Kooyman $\&$ Burns 1999). The population status of emperor penguins is potentially an important indicator of possible trends in both fast ice, pack ice and distributions of prey species (Ainley 1983, Barber-Meyer et al. 2008), yet little is currently known of the impact of different fast ice conditions on the breeding ecology of this species. Recent work has further suggested that emperor penguins may be vulnerable to climate change and variability, including shifts in the Semi-Annual Oscillation (SAO) and Antarctic Oscillation (AAO) in atmospheric circulation (Weimerskirch et al. 2003, Ainley et al. 2005, Jenouvrier et al. 2005a,b, Barber-Meyer et al. 2008).

Emperor penguins are unique in that they breed on fast ice in winter (Prévost 1961, Kooyman 1993, Wienecke \& Robertson 1997) and remain intimately associated with the ice until the following summer. Key phases of the emperor penguin breeding cycle at Pointe Géologie $\left(\sim 66.7^{\circ} \mathrm{S}, 140.0^{\circ} \mathrm{E}\right.$; close to the French station Dumont d'Urville) as they relate to fast ice are depicted schematically in Fig. 1 (after Jouventin et al. 1995). In Adélie Land, the penguins arrive at the colony in March/April, after the fast ice has formed (Jouventin et al. 1995). Egg laying takes place on the
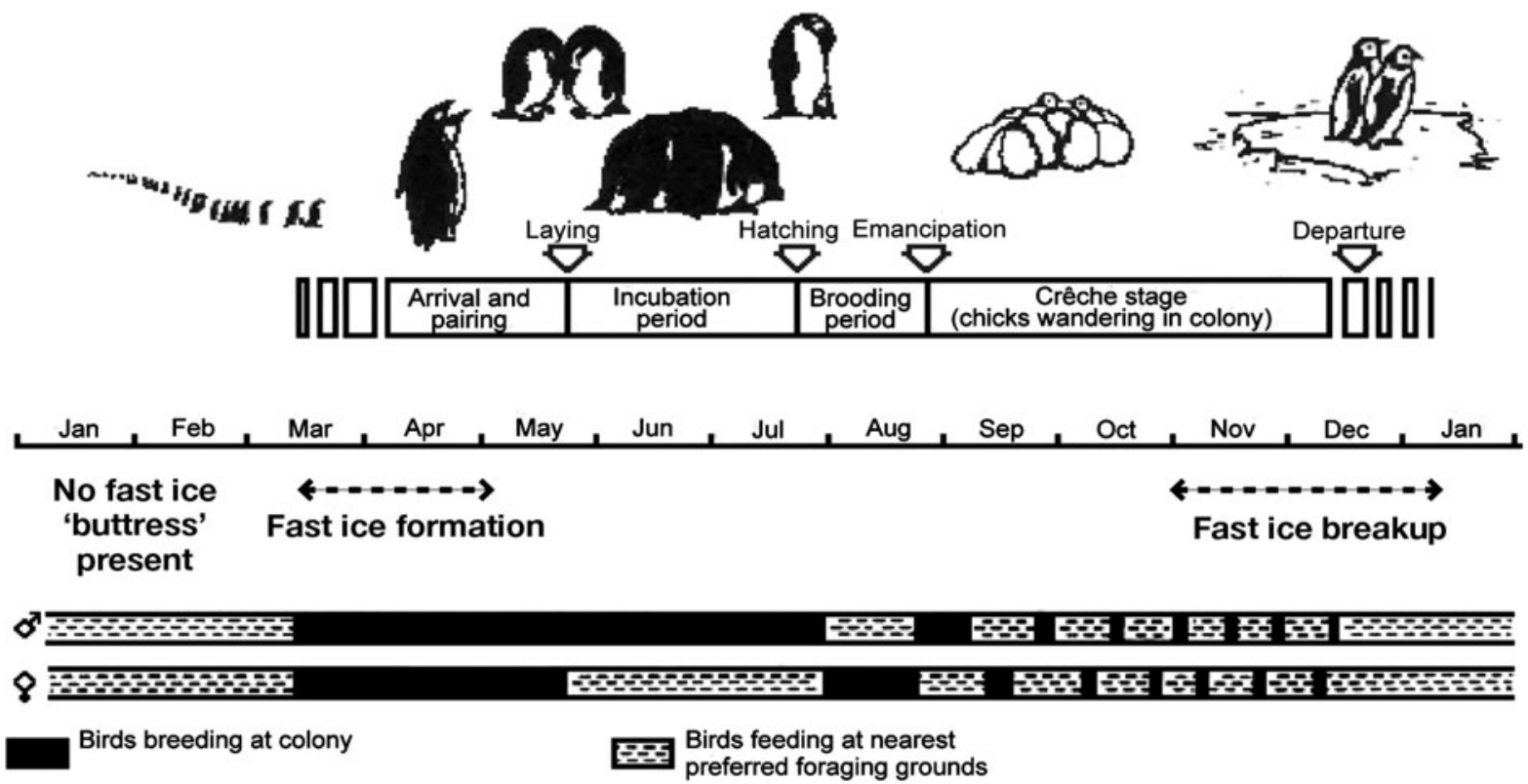

Fig. 1. Schematic representation of key dates in the emperor penguin annual breeding cycle at Pointe Géologie $\left(66.7^{\circ} \mathrm{S}, 140.0^{\circ} \mathrm{E}\right.$, Adélie Land). The ranges of the observed timing of fast ice 'buttress' annual formation and final break-up for the period 1992 to 1999 are marked. Periods when adult birds were away from the colony (i.e. at sea) are indicated. After Jouventin et al. (1995) 
ice in mid-May, after which the females leave for the ice edge (having fasted for $\sim 45 \mathrm{~d}$ ) and the male remains to incubate the egg. The eggs hatch in late July, and the female returns to relieve the male. At this stage, the male has fasted for $\sim 4 \mathrm{mo}$, losing $\sim 20 \mathrm{~kg}$ or nearly half its body weight (Groscolas 1988). The male then leaves to feed for $\sim 20 \mathrm{~d}$ (on squid, krill and small fish; Cherel \& Kooyman 1998), before returning to feed the chick (Robertson 1994), followed by another change in roles. When the chick is thermally emancipated ( 50 d old), it enters a crêche. From July at Pointe Géologie, both parents take turns to nurture the chick, with the non-carer shuttling between the colony and the fast ice edge for food (Ancel et al. 1992, Rodary et al. 2000, Zimmer et al. 2007). The duration of their return journey depends on the extent of the surrounding fast ice. Surviving chicks fledge in late November/ December, and depart the colony in DecemberJanuary.

For successful breeding, the fast ice should ideally provide a stable platform throughout much of the season, but with distances between the colony and the nearest food (open water) not being too great. Fast ice break-up should then occur in late spring, allowing the penguins to exploit the seasonal food increase (Kirkwood \& Robertson $1997 \mathrm{a}, \mathrm{b})$, but not too early in order to allow for successful chick fledging (Kooyman et al. 2000). From this follows that spatio-temporal variability and changes in fast ice distribution relative to the breeding cycle will have an immediate impact on penguin breeding success and demography, leading to marked interannual differences in breeding success. This factor was investigated in the present study by combining satellite-derived information on fast ice behaviour with information on emperor penguin breeding success at Pointe Géologie. Although records for this species extend back to the early 1950s and have received much recent attention due to a major decrease in the number of adult breeding pairs from about 1975 to 1982 (Barbraud \& Weimerskirch 2001), only the period 1992 to 1999 is analysed here. Previous research has correlated the population parameters of this penguin colony with overall pack ice extent and sea surface temperature (e.g. Barbraud \& Weimerskirch 2001, Jenouvrier et al. 2005a,b, Barber-Meyer et al. 2008). Ours is the first study to analyse the impact of temporal variability in Antarctic fast ice distribution, but not the first to emphasize the importance of proximity of the fast ice edge to a colony (Kooyman 1993).

\section{MATERIALS AND METHODS}

The areal extent and variability of fast ice along the Adélie Land coast were mapped using time series of
NOAA Advanced Very High Resolution Radiometer (AVHRR) visible and thermal infrared (TIR) satellite images collected at Casey Station $\left(66.28^{\circ} \mathrm{S}, 110.53^{\circ} \mathrm{E}\right)$. The AVHRR sensor is a 5-channel scanning radiometer with a best ground resolution of $1.1 \mathrm{~km}$ at nadir (Cracknell 1997, Kidwell 1997). The period covered began in 1992 due to a lack of sufficient AVHRR scans of the region of interest prior to this date and ended in 1999 (work is underway to extend the analysis forward in time).

While cloud cover is a limiting factor for visible-TIR data, enough data passes were acquired to provide sufficient cloud-free images to resolve synoptic-scale formation and break-up events. Of 10297 AVHRR images processed, 881 were selected for fast ice analysis, these being the best for each clear (cloud-free) day. The aim was to analyse as many cloud-free images as possible to resolve synoptic-scale variability in fast ice distribution around the penguin colony. In addition, a smaller set of cloud-free images was obtained from the Arctic and Antarctic Research Center (AARC) at Scripps Institution of Oceanography, comprising 227 Defense Meteorological Satellite Program (DMSP) Operational Linescan Imager (OLS) images $(2.7 \mathrm{~km}$ resolution) and 94 NOAA AVHRR images at $4 \mathrm{~km}$ resolution. The analysis also included 2 images (spatial resolution $140 \mathrm{~m}$ ) from the US Argon surveillance satellite programme, originally acquired in 1963 and obtained from the USGS EROS Data Center (available at: edcsns17.cr.usgs.gov/EarthExplorer/).

Initial image processing was carried out using the Common AVHRR Processing System (CAPS) (Hill 2000). This initially produces 3 brightness temperature $\left(T_{\mathrm{B}}\right)$ bands (AVHRR channels 3 to 5 ) to create an Ice Surface Temperature (IST) map (after Key 2002) and to enable cloud clearing (after Key 2002 and Williams et al. 2002). Fast ice area was then calculated from these data through a multi-step process involving user intervention. The first step involved correcting for anomalously warm pixels at the coast due to adiabatic warming by seaward-flowing katabatic winds. This was achieved by interpolating IST values to fast ice at a distance of 15 pixels to the North/South and East/ West. The coastline for ice sheet (land) masking was obtained from Lorenzin (2000). Step 2 involved detecting open water and thin sea ice areas by their thermal signatures. Following this, old ice (as opposed to newly-formed ice) was identified using 2 rules: the difference between the IST and $T_{\mathrm{B}}$ (band $4,10.3$ to $11.3 \mu \mathrm{m}$ ) for a given pixel is $\pm 1 \mathrm{~K}$ and the IST is $<250 \mathrm{~K}$. The final step, i.e. determination of the fast ice area, initially applied a Sobel edge-detection algorithm (Gonzalez \& Woods 1992) to identify all pixels adjacent to the coast. A segmentation algorithm then assigned a unique value to each old ice area. Finally, all pixels adjacent to the coast were examined using both the 
segmented and edge-detected images. If a pixel had a value (i.e. it was segmented old ice), then this segment was assumed to be attached to the coast. This segment's value was noted and every pixel with the same value was classified as fast ice. The area was then the product of the number of fast ice pixels and the resolution of each pixel.

A number of factors affect the accuracy of this technique. Poorly navigated images and large sensor scan angles detrimentally impact image segmentation, and every effort was taken to circumvent this. Moreover, sub-pixel scale clouds and leads remain unresolved and, together with water vapour from leads and polynyas, can contaminate the $T_{\mathrm{B}}$. In spite of these potential shortcomings, the algorithm gives reasonable and consistent results. The accuracy of the AVHRR-derived fast ice extent retrievals was tested by comparison with near-contemporary results from higher resolution satellite microwave data, i.e. from the Radarsat-1 ScanSAR (spatial resolution $100 \mathrm{~m}$ over a $500 \mathrm{~km}$ swath) obtained from the Alaska Satellite Facility. The latter were derived from a 'snapshot' study of East Antarctic fast ice by Giles et al. (2008) using 4 SAR images averaged over the period 2 to 18 November 1997. This gave an areal extent of $\sim 24700 \mathrm{~km}^{2}$. The comparative AVHRR-derived extent was $\sim 22240 \mathrm{~km}^{2}$ (average for 3 to 14 November 1997). This is $\sim 10 \%$ less than the SAR estimate, although the estimates (images) were not exactly contemporary. Time series of ScanSAR images, in combination with bathymetric data derived from Porter-Smith (2003), were also used to determine the distribution of grounded icebergs. At the $5.3 \mathrm{GHz}$ frequency $(\lambda=5.6 \mathrm{~cm})$ of the ScanSAR, icebergs can be resolved as high backscatter (bright) targets that are, in general, readily distinguishable from sea ice under cold conditions (Willis et al. 1996).

In addition, an estimate was made from the AVHRRderived fast ice extent product of the direct-path distance between the colony at Point Géologie and the nearest open water or thin ice. This represented the shortest distance that the penguins would have to travel across consolidated fast ice in order to reach foraging grounds. A caveat is that small leads and breaks in the fast ice remain unresolved in this satellite analysis, but may be used by the penguins.

Since the early 1950s, breeding success of emperor penguins at Point Géologie has been estimated as the number of fledged chicks counted in late November divided by the number of breeding pairs. Weather permitting, the ornithologist overwintering at nearby Dumont d'Urville visits the colony every day during the breeding period to count the number of abandoned eggs and dead chicks. Given this high observation effort, we are confident that the precision and accuracy of breeding success estimates are high for the study period.
In their study, Barbraud \& Weimerskirch (2001) examined overall sea ice (i.e. pack ice) extent, rather than fast ice extent, for its potential impact on the emperor penguin colony at Pointe Géologie. Here, we examine possible relationships between variability in fast ice extent and the extent and characteristics of the surrounding pack ice (including the Mertz Glacier polynya to the immediate east) using both AVHRR data and daily sea ice concentration data from the DMSP Special Sensor Microwave/Imager (SSM/I) for the sector 135 to $145^{\circ} \mathrm{E}$. The latter were obtained from the US National Snow and Ice Data Center for the period 1992 to 1999 inclusive (Comiso 1995, 2002). Statistical correlations between penguin breeding success and (1) fast ice extent and distance, and (2) fast and pack ice extent, were examined using the square of the Pearson product moment correlation coefficient $\left(\mathrm{r}^{2}\right)$. This value can be interpreted as the proportion of the variance in $y$ attributable to the variance in $x$.

The effect of variable atmospheric forcing on fast ice variability was determined using meteorological data from the French coastal station Dumont d'Urville $\left(66.66^{\circ} \mathrm{S}, 140.02^{\circ} \mathrm{E}\right.$, WMO \#89642, elevation $43 \mathrm{~m}$ above mean sea level), obtained from the SCAR READER project (www.antarctica.ac.uk/met/READER/). Synoptic-scale circulation patterns were examined using analyses from the Australian Bureau of Meteorology Global Assimilation and Prediction System, or GASP (Seaman et al. 1995).

We also carried out a preliminary analysis to determine whether changes in the Southern Annular Mode (SAM) and/or Southern Oscillation Index (SOI) underpin the interannual variability observed in fast ice distribution and emperor penguin breeding success. The SAM is the dominant mode of variability in the pattern of atmospheric circulation around Antarctica (see Simmonds \& King 2004 and references therein), and has been shown to have a strong impact on Antarctic sea ice distribution and temperature, e.g. Hall and Visbeck (2002), Liu et al. (2004), Lefebvre et al. (2004). The SAM influence on fast ice was examined using monthly SAM Index values derived using the algorithm of Marshall (2003) and obtained from the British Antarctic Survey at: www. nerc-bas.ac.uk/icd/gjma/sam.html. There is also regional evidence of strong El Niño-Southern Oscillation (ENSO) teleconnections with pack ice extent in the Antarctic (e.g. Kwok \& Comiso 2002, Stammerjohn et al. 2008). Potential relationships are examined here using SOI values from the Australian Bureau of Meteorology (available at: www.bom.gov. au/climate/current/soihtm1.shtml). These were calculated as the standardised anomaly of the mean sea level pressure difference between Tahiti and Darwin. 




Fig. 2. NASA Terra MODIS image (resolution $250 \mathrm{~m}$ ) from 23 October 2001, showing the fast ice buttress and study region. Pack ice drifts from $\mathrm{E}$ to $\mathrm{W}$ in the coastal region. MoDis image courtesy NASA

\section{RESULTS}

\section{The role of grounded icebergs}

A large promontory of annual fast ice, hitherto termed the 'buttress', dominates the Adélie Land coast between the Dibble Iceberg Tongue (at $\sim 135.0^{\circ} \mathrm{E}$ ) and Commonwealth Bay $\left(\sim 142.7^{\circ} \mathrm{E}\right)$ outside the austral summer (Fig. 2). At its maximum extent in winter, this fast ice tract extends as far as 100 to $120 \mathrm{~km}$ offshore, with a zonal coverage of $\sim 350 \mathrm{~km}$. The northern boundary, which is closely aligned with the continental shelf break (Fig. 3), is typically separated from the moving pack ice by a series of flaw leads, while the eastern margin is closely associated with the adjacent Mertz Glacier Polynya (Massom et al. 2001). Comparison of the fast ice extent shown in Fig. 2 with the iceberg distributions and bathymetric information in Fig. 3 shows that lines of numerous small icebergs grounded on banks/shoals $<350$ to 400 m deep are key determinants of fast ice maximum areal extent. The grounded icebergs act as pinning points for thermodynamic fast ice growth, and also dynamic growth by intercepting pack ice. The regional distribution of grounded versus drifting icebergs has been determined by analysis of time series of co-registered Radarsat ScanSAR images from 1 to 29 September
1999 (B. Giles, unpubl. data). These icebergs mainly originate from calving of local glaciers (see Fig. 2, this paper and discussion by Frezzotti \& Polizzi 2002). A secondary source is icebergs that drift into the region with the East Wind Drift (EWD) poleward of the southern boundary of the Antarctic Circumpolar Current (at $\sim 64^{\circ} \mathrm{S}$ in this region; Orsi et al. 1995).

The V-shaped inlet in the fast ice to the NW of Dumont d'Urville overlays an oceanic trough as deep as $\sim 700$ to $1000 \mathrm{~m}$ between the Adélie and Dibble Banks (Fig. 3), which cuts into the continental shelf to the NW of Dumont d'Urville and almost reaches the coast at the base. This is largely devoid of grounded icebergs and is the site of ephemeral mid-season breakouts (hitherto referred to as 'trough clearouts'). This phenomenon is of major significance to the emperor penguin population at Pointe Géologie, as shown in the next section.

\section{Interannual variability in fast ice and emperor penguin breeding success}

Results from the satellite analysis of buttress fast ice extent and distance between the Pointe Géologie emperor penguin colony $\left(66.7^{\circ} \mathrm{S}, 140.0^{\circ} \mathrm{E}\right)$ and the nearest open water are shown in Fig. $4 \mathrm{a} \& \mathrm{~b}$, respec- 


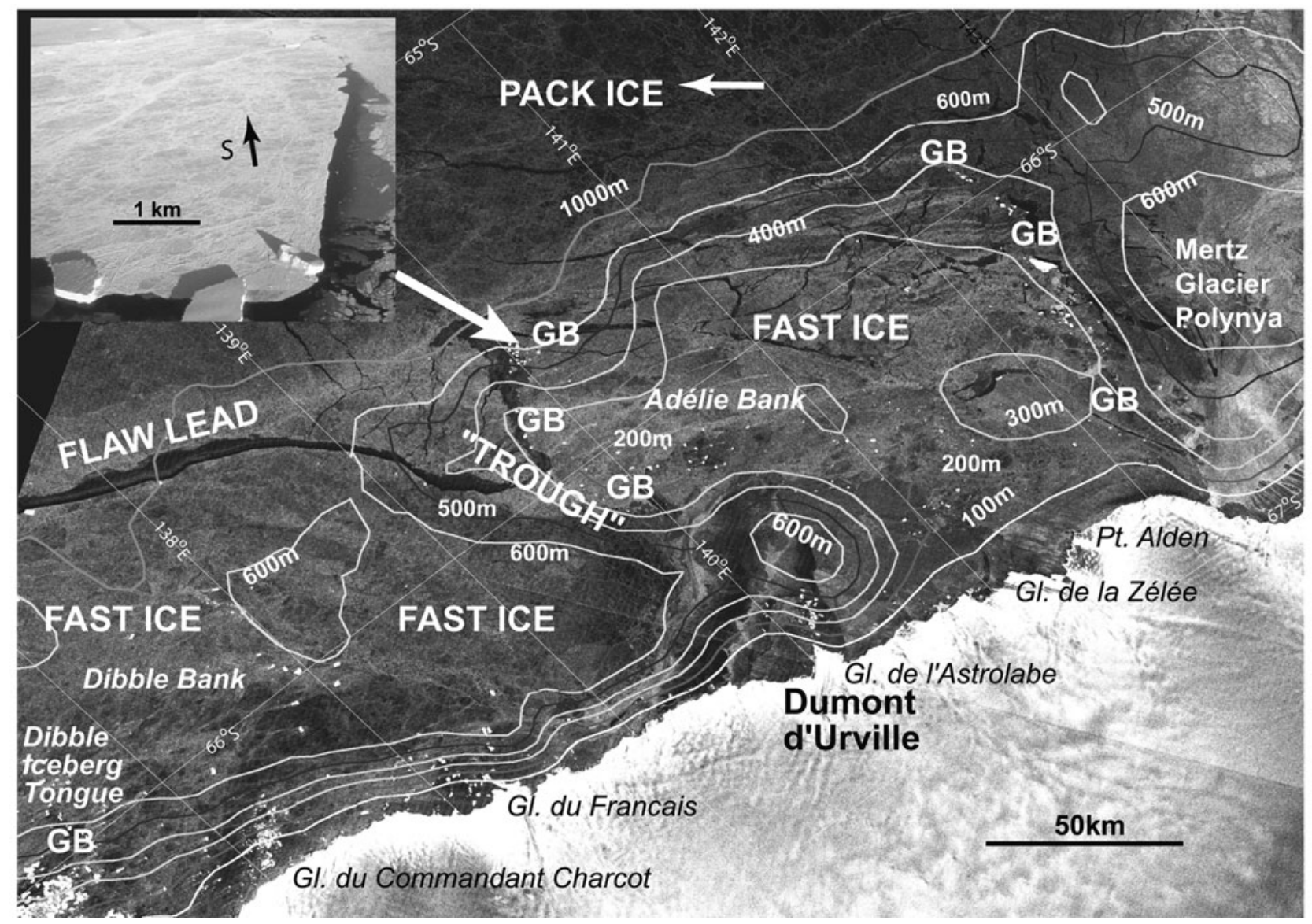

Fig. 3. Radarsat ScanSAR image of the 'buttress' region on 7 August 1999, with ocean depth contours superimposed (source: http://www.marine.csiro.au/dods/nph-dods/dods-data/climatology-netcdf/terrainbase.nc.html). Fast ice distribution is determined by the distribution of icebergs grounded on banks $<350$ to $500 \mathrm{~m}$ (approximate locations marked GB). Bergs emanate from local glaciers (marked) and from the region to the east. The inset panel shows an oblique aerial photograph of fast ice anchored by small grounded icebergs in the region marked by the arrow. Data courtesy NASA/Radarsat International, ORadarsat International 1999

tively. A pronounced feature is the high degree of interannual variability. While patterns of formation, break-up and areal extent are close to the 8 yr mean in some years, e.g. 1992, significant departures are apparent at other times. Heavy (extensive) fast ice years were experienced from 1994 to 1997, and particularly in 1994. On the other hand, below-average extents occurred in 1998 and 1999, and in 1993 in particular. Maximum fast ice extent varied substantially from $\sim 56500 \mathrm{~km}^{2}$ in 1994 to $\sim 37650 \mathrm{~km}^{2}$ in 1998. The timing of the annual maximum extent also varied substantially, from mid-May in 1998 to late September in 1994 (Table 1).

The approximate timing of annual buttress formation and break-up (summarised in Table 1) also varied substantially among years. Although formation typically began in early- to mid-April, it ranged from mid-March (e.g. in 2001, not shown) to mid-May (e.g. 1992). While break-up occurred as early as November in certain seasons e.g. in 1993 (i.e. coincident with the annual melt-back of pack ice; Gloersen et al. 1992), it can be as late as early February (e.g. in the 1996-1997 season). In general, complete late season break-up occurred rapidly once the buttress was no longer protected by pack ice to the north, which is also annual in this region. However, a vestige typically persisted throughout the summer melt period along the eastern flank of the Dibble Iceberg Tongue, where it was maintained by ice dynamics within the coastal EWD. This also varied considerably among years, ranging in extent from virtually zero in early 1994 and 1999 to $\sim 10000 \mathrm{~km}^{2}$ in early 1996.

Possible relationships between fast ice and emperor penguins at Pointe Géologie were examined by comparing results on buttress areal extent (Fig. 4a) and the shortest distance from the colony to open water (Fig. 4b) (both based on daily data) with the annual breeding success record (Fig. 4c). An assumption is 

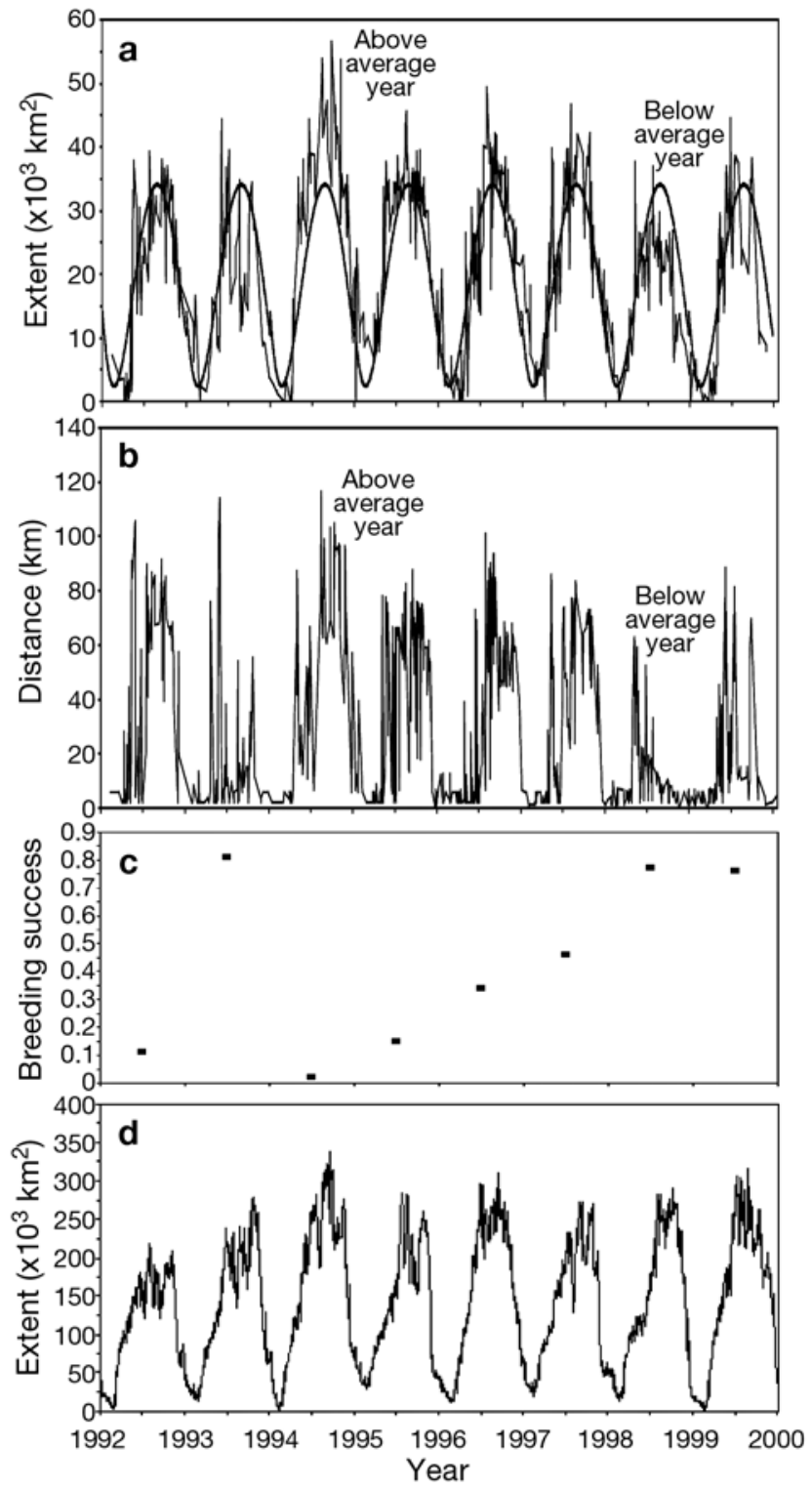

Fig. 4. (a) Fast ice buttress areal extent, (b) distance from penguin colony to nearest open water/thin ice, (c) emperor penguin annual breeding success at Pointe Géologie (no. fledged chicks in late November/no. of breeding pairs; after Barbraud \& Weimerskirch 2001), and (d) monthly mean overall pack ice extent in the sector 135 to $145^{\circ} \mathrm{E}$, derived by applying a $15 \%$ threshold to SSM/I ice concentration data 1992 to 1999. In (a), a 4 th order polynomial is fitted to all points plotted as extent versus day of year, and serves as an approximate mean annual extent for 1992 to 1999

made that other factors, such as human disturbance, were negligible over this period (emperor penguins at Pointe Géologie have been exposed to a range of human activities for $50 \mathrm{yr}$ and may have habituated to non-invasive human activities).

Insight into the impact of fast ice on penguin breeding success can be gained by initially comparing data from 1993 with both 1992 and 1994 in Fig. 4. Penguin breeding success in 1993 was, at $81 \%$, the highest in the $8 \mathrm{yr}$ record and the second highest over the entire breeding record (dating back to 1952, with the highest overall being $86 \%$ in 1966). In 1993, this coincided with below-average fast ice extent coupled with anomalously short distances between the colony and the nearest open water (food source). Although large distances did occur at times, these did not persist throughout critical periods in the penguin breeding cycle, i.e. from July to December when the adult birds take turns to shuttle back and forth between the colony and the food source (see Fig. 1). As such, the birds had relatively ready access to open water (and food) in 1993.

In contrast, the following year (1994) was characterised by extreme fast ice conditions, i.e. above average values of not only fast ice extent but also direct distance, the largest over the $8 \mathrm{yr}$ record in both cases. This coincided with a record low penguin breeding success of $2.4 \%$, or a survival of only 80 chicks (Micol \& Jouventin 2001). Similarly, the very low breeding success of $11 \%$ in 1992 coincided with the persistence of relatively large distances between the colony and nearest open water, although the overall fast ice extent approximated the 8 yr average (Fig. 4a).

The strong relationship between fast ice and penguin breeding success is also apparent in the other years. The other 2 prominent highs in breeding success in Fig. 4c, i.e. in 1998 (77\%) and 1999 (76\%), again coincided with lower-than-average fast ice extents coupled with anomalously short distances between colony and open water, e.g. $<10 \mathrm{~km}$ in 1998. The 3 years of partial recovery in breeding success following the disastrous breeding season in 1994 (Fig. 4c) coincided with moderately heavy fast ice years. The low to

Table 1. Approximate dates of annual formation and disintegration of the fast ice buttress, and the maximum annual fast ice extent and timing, as determined from satellite data analysis (1992 to 1999). Here, date of formation refers to the approximate time when the area of the buttress exceeded a threshold of $10000 \mathrm{~km}^{2}$ in the austral autumn, and date of disintegration was set when the area fell below the same threshold in the austral spring-summer and remained so for a minimum of $7 \mathrm{~d}$. Exact dates cannot be given due to gaps in the satellite image record

\begin{tabular}{|lllcl|}
\hline Year & $\begin{array}{l}\text { Time of } \\
\text { formation }\end{array}$ & $\begin{array}{l}\text { Time of } \\
\text { disintegration }\end{array}$ & $\begin{array}{c}\text { Area of } \\
\text { maximum } \\
\text { extent }\left(\mathrm{km}^{2}\right)\end{array}$ & $\begin{array}{l}\text { Time of } \\
\text { maximum } \\
\text { extent }\end{array}$ \\
\hline 1992 & Mid May & Early February 1993 & 39300 & Late July \\
1993 & Mid April & November & 44000 & Early June \\
1994 & Early April & Mid-February 1995 & 56500 & Late September \\
1995 & Early April & Mid-January 1996 & 45700 & Mid August \\
1996 & Early May & Early February 1997 & 49400 & Early August \\
1997 & Mid April & Early February 1998 & 46700 & Early August \\
1998 & Mid April & Early December & 37650 & Mid May \\
1999 & Early May & Late Nov./early Dec. & 44500 & Early July \\
\hline
\end{tabular}




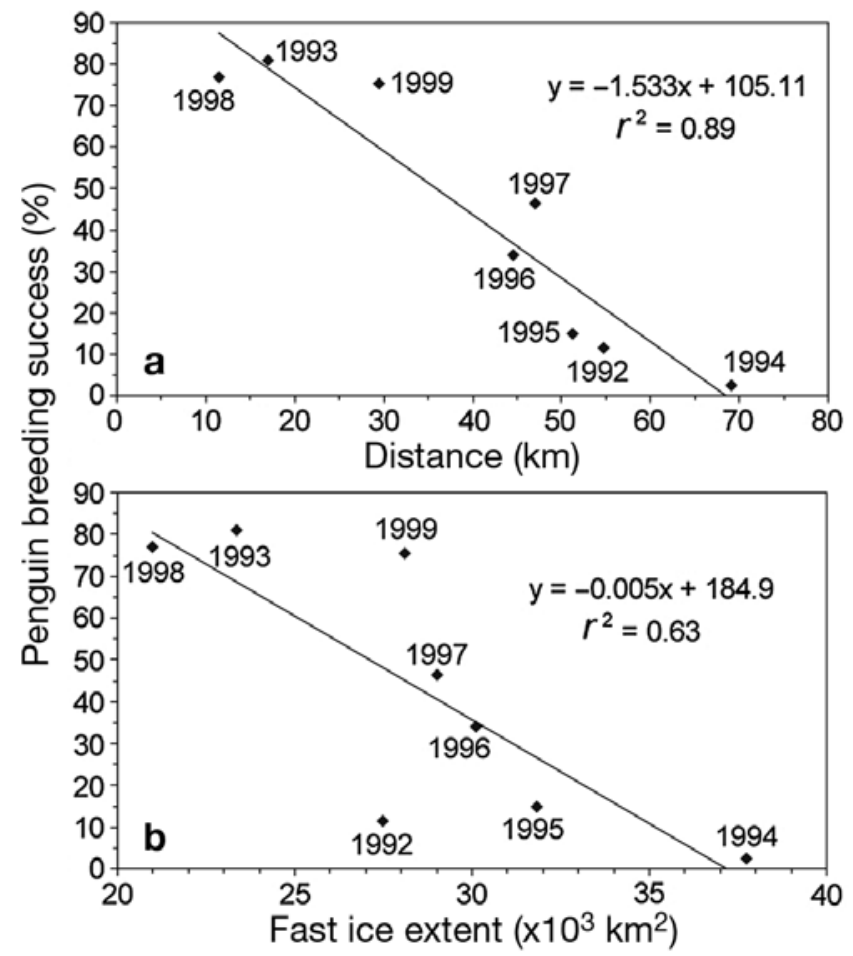

Fig. 5. Scatter plots of emperor penguin breeding success ([no. fledged chicks in late November] / [no. of breeding pairs] $\times 100)$ at Pointe Géologie (1992 to 1999) versus (a) shortest straight-line distance between the colony and the nearest open water, and (b) extent of the fast ice buttress, both averaged over the June to December period and with linear regressions applied

moderate breeding success of $15 \%$ (in 1995) to $46 \%$ (in 1997) coincided with above-average buttress annual extents and moderate-to-large distances of $>40 \mathrm{~km}$. The latter persisted throughout the critical May to December breeding period.

The relationship between annual breeding success and mean fast ice extent and distance for the June to December period is shown in Fig. 5. This period is chosen because it covers the incubation and chick rearing periods, both of which impact the overall annual breeding success. Although based upon only $8 \mathrm{yr}$ of data, a good correlation is apparent between breeding success and distance $\left(\mathrm{r}^{2}=0.89\right)$; success is higher when overall fast ice extent is lower $\left(\mathrm{r}^{2}=0.63\right)$. This is due to the presence of 2 outliers, in 1992 and 1999 (Fig. 5b). The fact that fast ice extent was similar in these 2 years, yet the breeding success was drastically different, shows that fast ice extent alone is in this case a less robust indicator of penguin breeding success than distance (note that the distance was high in 1992 [Fig. $5 a])$. In other words, distance, while related to fast ice extent, is a more immediate and useful descriptor of fast ice as it relates to penguin breeding success at
Table 2. Values of buttress areal extent, nearest distance between the emperor penguin colony and open water, SAM Index (Southern Annular Mode Index), Southern Oscillation Index (SOI) (all averaged over the June to December period) and penguin breeding success at Pointe Géologie, 1992 to 1999. For the SOI, sustained negative and positive values indicate El Niño and La Niña events, respectively

\begin{tabular}{|ccccrr|}
\hline Year & $\begin{array}{c}\text { Breeding } \\
\text { success }(\%)\end{array}$ & $\begin{array}{c}\text { Buttress } \\
\text { extent }\left(\mathrm{km}^{2}\right)\end{array}$ & $\begin{array}{c}\text { Distance } \\
(\mathrm{km})\end{array}$ & $\begin{array}{r}\text { SAM } \\
\text { index }\end{array}$ & SOI \\
\hline 1992 & 11 & 27469 & 54.73 & -0.07 & -6.79 \\
1993 & 81 & 23376 & 16.99 & 1.59 & -8.53 \\
1994 & 2 & 37753 & 69.09 & -0.45 & -13.69 \\
1995 & 15 & 31815 & 51.31 & -0.15 & 0.17 \\
1996 & 34 & 30105 & 44.58 & -0.95 & 6.21 \\
1997 & 46 & 29021 & 47.03 & -0.27 & -15.76 \\
1998 & 77 & 20996 & 11.45 & 1.72 & 11.73 \\
1999 & 76 & 28105 & 29.48 & 1.26 & 6.07 \\
\hline
\end{tabular}

Pointe Géologie. Again, this relationship is based upon 8 data points alone, and further investigation using longer time series is required.

Values of buttress areal extent, nearest distance, the SAM Index and the SOI (all averaged over the June to December period) are compared with penguin breeding success for 1992 to 1999 in Table 2. A prominent feature is the strong correspondence between high breeding success and high positive SAM Index values, i.e. in 1993, 1998 and 1999. For the $8 \mathrm{yr}$ time series, $\mathrm{r}^{2}$ values for the SAM Index versus (1) distance and (2) breeding success are 0.75 and 0.70 , respectively (SAM Index versus buttress areal extent: $\mathrm{r}^{2}=0.58$ ). That the values are similarly high again suggests that winddriven variability in fast ice distance plays a major role in determining interannual variability in penguin breeding success at this location.

Correlations are poorer between the SOI and fast ice/breeding success $\left(r^{2}=\right.$ of $0.31,0.17$ and 0.20 for distance, fast ice extent and penguin breeding success, respectively), and there is no clear pattern in the relationship over this short (8 yr) time series. The successful breeding seasons and below-average distances and fast ice extents in 1998 and 1999 corresponded to La Niña events (Table 2). However, the highly successful breeding season and relatively light fast ice conditions in 1993 correspond to an El Niño event, as did the very heavy fast ice and disastrous breeding season in 1994. In the same manner, the very strong El Niño event in 1997 coincided with a moderately successful breeding season. More detailed analysis of the relationship between both positive and negative phases of SAM/SOI and fast ice behaviour and penguin breeding success is beyond the scope of this paper, but is planned using longerterm datasets. 

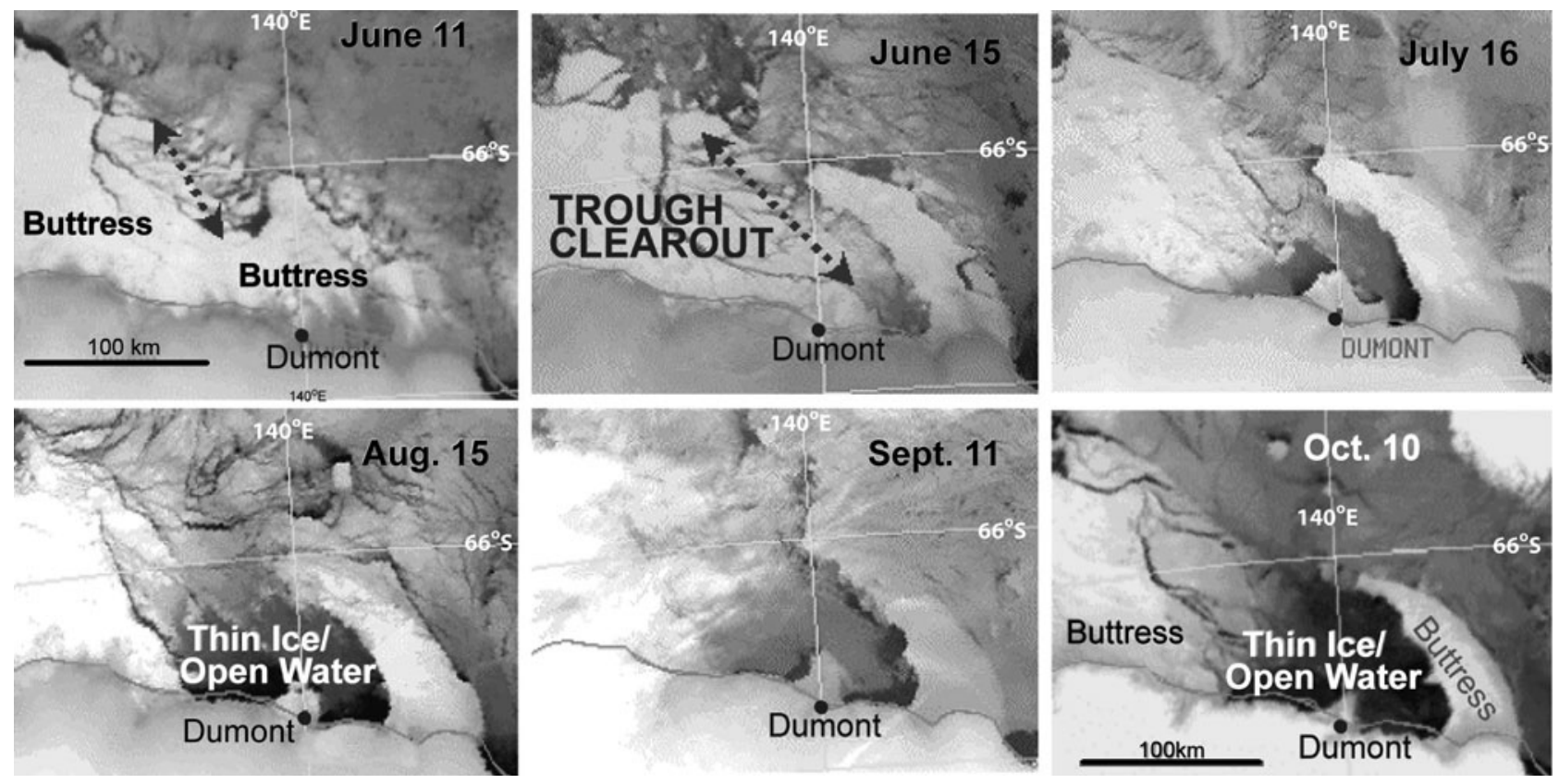

Fig. 6. Sequence of AVHRR thermal infrared (channel 4) images of fast- and pack-ice conditions along the Adélie Land coast of East Antarctica from 11 June to 10 October 1998, showing the breakout of fast ice in the ocean trough region

\section{The impact of trough breakout events: 1998 case study}

In all of the above cases, the nearest distance between the penguin colony and open water was primarily linked to the occurrence (or otherwise) of mid-season fast ice clearouts and subsequent reformations over the deeper water trough to the north-northwest of Dumont d'Urville. In general, intermittent and ephemeral trough clearouts occurred when storms traversed the region (see Fig. 4a,b), with fast ice reforming a few days later. At certain times, however, trough clearouts persisted substantially longer. Fast ice conditions in 1998, for example, were dominated by the anomalous persistence of one such event, with an extensive trough clear-out between the northern boundary of the buttress and coast in the vicinity of the penguin colony lasting from mid-June to October (Fig. 6). This resulted in the lowest mean fast ice extent and foraging distance in the 8 yr series (see Table 2 and Fig. 4b), and contributed to an unusually early seasonal break-up of the entire eastern and central parts of the buttress in 1998 (i.e. early November).

June to October wind data from Dumont d'Urville between 1956 and 2001 were analysed to discern any anomalous atmospheric behaviour for 1998. Fig. $7 \mathrm{a}$ shows a wind rose analysis over the long-term mean, and indicates a predominantly southeasterly airflow at the station. For the full 45 yr record, $63.4 \%$ of observed winds were from the southeast cardinal. For June to October 1998, it is clear that winds from bearing $135^{\circ} \mathrm{T}$ dominated the 5 mo period (Fig. $7 \mathrm{~b}$ ), with $35 \%$ of winds being recorded from this cardinal compared to a long-term mean of $26.5 \%$. Of the winds measured from this cardinal, $66.5 \%$ were in excess of $10 \mathrm{~m} \mathrm{~s}^{-1}$. Moreover, $71.5 \%$ of all measured winds were from the southeast quarter.

The role of winds in driving the anomalous persistence of the trough breakout in 1998 is confirmed in Fig. 8, which shows (a) the mean wind direction (vector mean), (b) mean wind speed and (c) the persistence of Dumont d'Urville winds for the June to October period from 1960 to 1999 . Here, persistence is defined as the

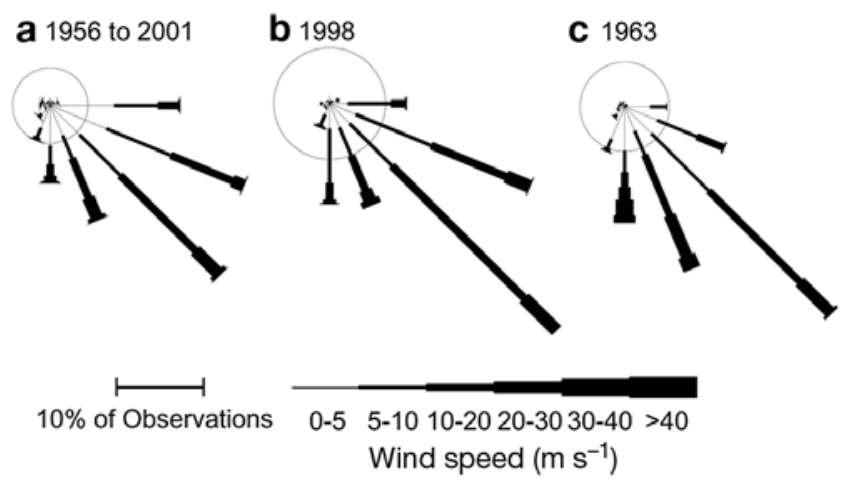

Fig. 7. Wind rose diagrams of wind speed and direction for the June to October period inclusive for Dumont d'Urville (WMO \#89642) for (a) 1956 to 2001, (b) 1998, and (c) 1963, based upon 3-hourly data (data courtesy the SCAR READER Project). The length of each 'rose' gives a measure of the percentage frequency of wind from that cardinal direction, while the width of the rose relates to wind strength 

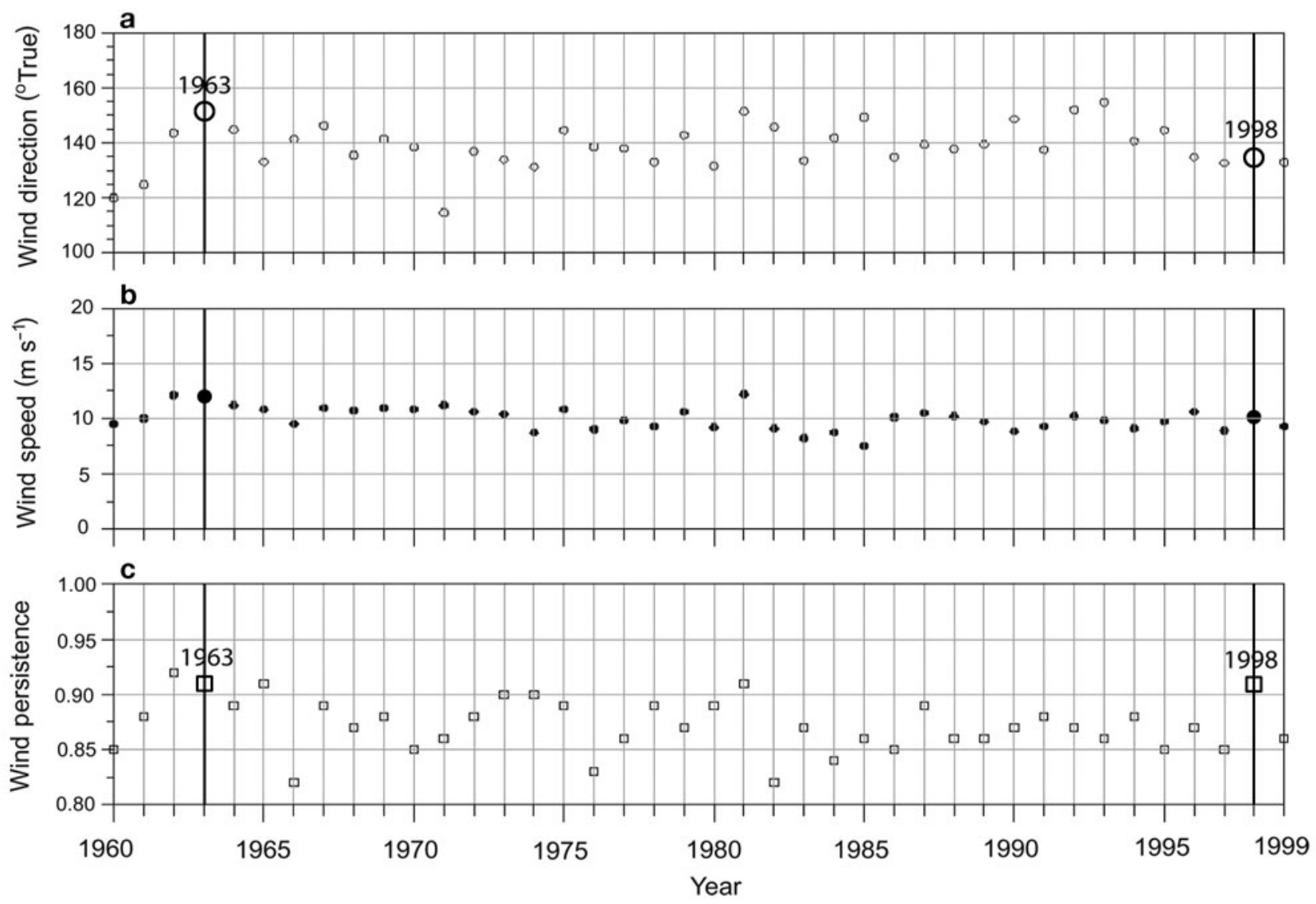

Fig. 8. (a) Mean wind direction (vector mean), (b) mean wind speed and (c) the persistence of the wind (ratio of the mean vector speed to the mean scalar speed) at Dumont d'Urville for the June to October period from 1960 to 1999. Data courtesy of the SCAR READER Project. 1963 and 1998 case studies marked

ratio of the mean vector speed to the mean scalar speed (Panofsky \& Brier 1965), with values approaching 1 and 0 denoting high and low persistence, respectively. The winds in 1998 were highly persistent (value of 0.91 ) (Fig. 8). Persistences of $>0.90$ were only recorded in 5 years, with the highest being 0.92 in 1962. The mean wind speed in 1998 was near average for the $40 \mathrm{yr}$ record (1960 to 1999), with the mean direction being slightly more to the east of south-easterly than normal.

In summary, there was an apparent relationship between fast ice behaviour and wind direction (and strength) for the period 1992 to 1999. The extensive (above-average) fast ice extent in 1994 coincided with low winter temperatures and winds predominantly from the east-southeast. In contrast, the lower-thanaverage extent and distances in 1993 were associated with higher-speed winds from the south-southeast, with lower air pressure, higher temperatures and a high positive SAM Index value. Fast ice characteristics in 1996 and 1997 (of average extent and few trough clearouts) were associated with moderate winds from a more east-southeasterly direction on average. The anomalously low fast ice extent and distances to nearest open water in 1998 and 1999 (Fig. 4a,b) coincided with a change to strengthening winds with more of a south-southeasterly component and an associated increase in annual minimum (winter) temperature. This again corresponded with high positive SAM Index values. Hence, prevailing winds with a more easterly component tended to pack ice into the region, leading to more extensive fast ice. More southerly winds, on the other hand, had a stronger effect in dispersing the fast ice, generally leading to a smaller areal extent.

\section{Diminished fast ice from an earlier epoch: 1963 case study}

Detailed examination of possible relationships between the Pointe Géologie penguins and fast ice over the period of maximum population change (1975 to 1982) reported by Barbraud \& Weimerskirch (2001) is unfortunately limited by a lack of high-resolution satellite data from that time. Argon surveillance satellite images, however, provide tantalising glimpses (on 2 days only) of fast ice conditions from an earlier epoch, 

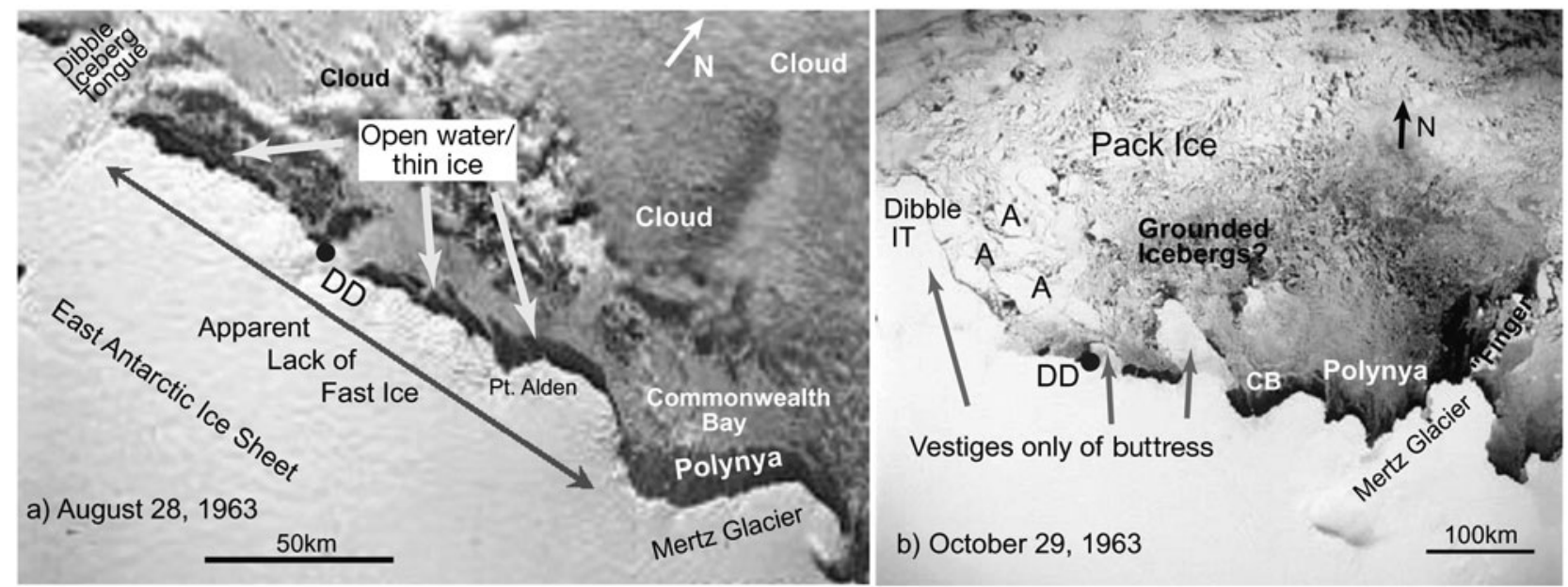

Fig. 9. US Argon spy satellite images of the Adélie Land coast from (a) 28 August 1963, and (b) 29 October 1963, showing an apparent lack of fast ice in the winter of 1963. DD: Dumont d'Urville, CB: Commonwealth Bay, A: fragments of broken out fast ice

i.e. in 1963 (Fig. 9). The visible image from 28 August 1963 appears to show an almost complete absence of fast ice along the Adélie Land coast from Commonwealth Bay to the Dibble Iceberg Tongue (DIT), apart from a small vestige in the immediate vicinity of Dumont d'Urville (i.e. around the penguin colony). Indeed, the coastal zone is dominated by an extensive linear polynya. Moreover, the image from 29 October 1963 shows a very small buttress limited to the immediate vicinity of Dumont d'Urville, the eastern flank of the DIT, and the grounded iceberg zone north of Point Alden. These images suggest that the fast ice buttress was much less extensive in the winter to early spring of 1963 compared with 1992 to 1999 . The conditions in 1963 corresponded to a high breeding success rate of $80.6 \%$ (Barbraud \& Weimerskirch 2001). Open water was available in close proximity to the penguin colony at that time.

How could fast ice conditions in 1963 be so strikingly different from the present conditions? Figs. 8 \& 9 shed light upon this. The year 1963 was meteorologically anomalous, with $33.5 \%$ of winds from the $135^{\circ} \mathrm{T}$ cardinal, and $63.5 \%$ of those winds in excess of $10 \mathrm{~m} \mathrm{~s}^{-1}$ and $66.6 \%$ from the southeast quarter. As in 1998, 1963 was characterised by an increased occurrence of southeasterly winds from bearing $135^{\circ} \mathrm{T}$ (Fig. $7 \mathrm{C}$ ) compared to the long-term mean (Fig. 7a). The directional persistence was also high at 0.91 . What set 1963 apart, however, was a higher-than-average mean speed and a mean wind direction significantly more into the south-southeast quadrant than in most years (Fig. 7). This translated to a significant number of very strong wind events $\left(>20 \mathrm{~m} \mathrm{~s}^{-1}\right)$ from the south and southsoutheast, which would have the effect of maintaining ice-free conditions along the coast. There are known problems with the Dumont d'Urville wind measure- ments prior to 1970, with the 'Papillon' anemometer then used over-estimating wind speeds (Periard \& Pettré 1993). The READER dataset used for the present study has been corrected for this effect following Murphy \& Pettré (1995), although the exact level of accuracy remains unknown. Although the wind speeds may be erroneous, the wind direction data are robust and the higher number of measurements from bearing $135^{\circ} \mathrm{T}$ is well established. In addition, the value of the SAM Index in August 1963 was, at -5.53, the 3rd lowest monthly mean value for the entire record (extending back to January 1957), and August 1963 was also an El Niño period (SOI = -7.43).

\section{Relationships between fast ice and regional pack ice}

We examined possible relationships between fast ice extent and characteristics of the surrounding pack ice. Fig. $4 \mathrm{~d}$ shows a plot of pack ice areal extent in the sector 135 to $145^{\circ} \mathrm{E}$, i.e. the region encompassing the buttress. Comparison with Fig. 4a suggests poor year-toyear correspondence between buttress areal extent and that of the surrounding pack, although the overall $r^{2}=0.74$. While the anomalously large buttress extent in 1994 (Fig. 4a) coincided with an above-average regional pack ice extent, so did the anomalously low fast ice extent in 1998. Moreover, an average fast ice year (1992) also coincided with the lowest regional pack ice extent in the entire 1978 to 1999 satellite record (not shown). Similarly, both the low and high pack ice extents in 1992 and 1994, for example, corresponded to very low penguin breeding success rates of 11.5 and $2.5 \%$, respectively (Fig. $4 \mathrm{c}$ ).

Although there is no clear pattern in the relationship between fast ice extent and overall regional pack ice 

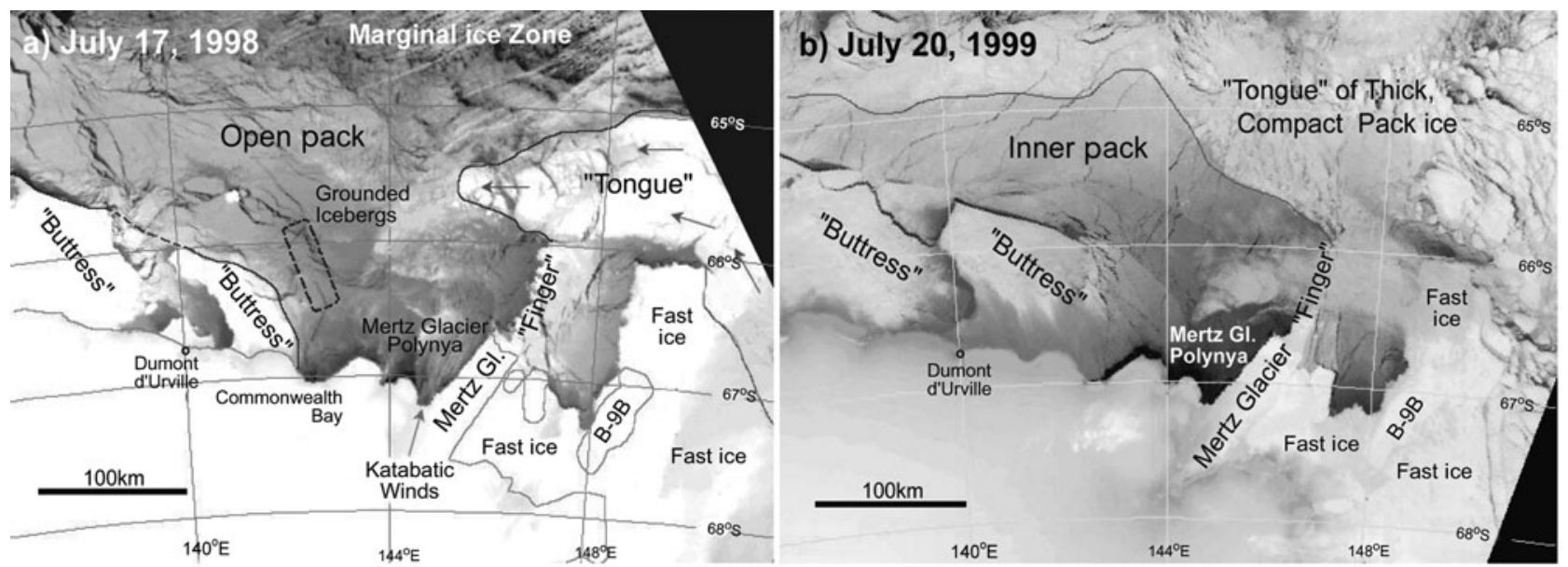

Fig. 10. NOAA AVHRR (5-channel scanning radiometer) channel 4 (thermal IR) images of the Adélie Land coast for (a) 17 July 1998, and (b) 20 July 1999, showing the relationship between fast ice extent and the presence/absence of the mid-pack zonal pack ice tongue. Lines are drawn in to show the approximate extent of the tongue. 'Finger' denotes a line of grounded icebergs connected by fast ice (see Massom et al. 2001 for details). AVHRR image courtesy of Australian Bureau of Meteorology

extent, a correspondence is apparent between buttress extent and the morphological characteristics of the pack, notably the presence/absence of a zonal tongue of highly-compact, thick pack ice about 100 to $200 \mathrm{~km}$ to the north-northeast of the fast ice (Fig. 10). Although this feature recurs annually and persists for substantial periods (see Massom et al. 2001), the timing of its initial formation varies from year to year due to variability in wind conditions, with potentially important ramifications for fast ice extent and penguin breeding success. The 9 yr minimum buttress extent in 1998, for example, coincided with a lack of a tongue until late July, whereas in 1999, early annual tongue development coincided with an extensive buttress (Fig. 10). While the exact mechanism behind this relationship is unknown, the presence of a well-developed tongue may protect fast ice to the south from the destructive impact of ocean swell propagating from the open ocean to the coast during major storms (the impact of swell on fast ice break-up is described by Crocker \& Wadhams 1989 and Langhorne et al. 2001). The eastward extent of the buttress is also intimately tied to ice production rates within the Mertz Glacier polynya, which are in turn affected by the presence/absence of the pack ice tongue (Massom et al. 2001), and affect the distance from the penguin colony to the nearest open water to the east-northeast. This illustrates the complexity of the inter-relationships that exist between fast ice, polynya and interior pack, and ultimately penguin breeding success. It is also an example of how both remotely-occurring and localised processes can affect fast ice habitat and underlines the need for a better understanding of the complex interactions of both, driven by variable atmospheric forcing.

\section{DISCUSSION}

The results presented suggest that fast ice and, in particular, distance to the fast ice edge (feeding grounds) from the colony and associated fast ice extent during the chick rearing period are major determinants of emperor penguin breeding success at Pointe Géologie. While the location of grounded icebergs, and therefore bathymetry, is a key factor affecting the extent of the annual fast ice buttress abutting the Adélie Land coast from $\sim 134$ to $143^{\circ} \mathrm{E}$, considerable spatio-temporal variability occurs in the fast ice coverage from one year to the next. Of key importance, because of their effects on distance (in particular), are the frequency, magnitude and duration of fast ice clearout events, and the eastward extent of the buttress (which is intimately tied to ice production in the Mertz Glacier polynya). All are dependent on wind direction, and there are strong correlations between low ice extent and distance plus breeding success and positive SAM events, although the impact of El Niño or La Niña events is less clear. More analysis is necessary on the effect of the different phases of modes of largescale atmospheric circulation, using a longer time series of fast ice data. Moreover, there appears to be a correspondence between fast ice extent and the presence/absence of a major zonal tongue within the pack ice zone in this region, again requiring further analysis.

The significance of trough clearout events is corroborated by winter observations of emperor penguins satellite-tracked from Pointe Géologie by Ancel et al. (1992) and Rodary et al. (2000). In early August 1997, Rodary et al. (2000) noted that foraging activity of females was con- 
centrated in the region to the north-northwest of Dumont d'Urville less than $\sim 60 \mathrm{~km}$ from the colony. This activity coincided with an extensive trough clearout (similar to that shown in Fig. 6) at the time of sampling. In contrast, no trough clearout events occurred in the previous August (1996), and foraging activity concentrated on the region $\sim 80$ to $110 \mathrm{~km}$ to the northeast of the colony, which is characterised by a recurrent flaw lead.

Similarly, the relatively large distances travelled in 1990 coincided with the lack of a major trough clearout (at least over the $3 \mathrm{wk}$ tracking period) (Ancel et al. 1992), and could have again contributed to the low breeding success of $15.5 \%$ in that year.

In the current study, the persistence of relatively large distances in both 1992 and 1994 (due in part to the lack of major trough clearout events) occurred at critical periods in the penguin breeding cycle, i.e. when the female departed the egg after a 2 mo fast, when the female relieved the male, and when the breeding adult birds subsequently took turns to shuttle back and forth between the colony and foraging zones at the fast ice edge to nurture the chick. Breeding male birds are particularly vulnerable during their first foraging trip after their annual 4 mo incubation fast (Jouventin et al. 1984, Rodary et al. 2000). At this critical stage in the breeding cycle, significant stress would be placed on a male bird that has lost much of its body weight during the annual fast, yet has to expend significant energy travelling large distances across extensive and compact fast ice to feed after being relieved by the returning female (Wienecke \& Robertson 1997). In 1994 (a disastrous breeding year), for example, many chicks were seen wandering in the colony after their first relief by the females, and were then found dead, indicating that a substantial number of males failed to return to the colony in time. While Jenouvrier et al. (2005a) have estimated adult annual survival up to 2001, the data are currently unsuitable for making comparisons between fast ice extent/distance and adult survival. Further analysis on the relationship between adult survival and fast ice extent on a slightly longer time scale using capture-recapture models should be performed in the future.

In less extensive fast ice years, e.g. 1993 and 1998, the predominance of short distances due to frequent and, at times, sustained trough clearout events and less extensive fast ice to the east-northeast would have resulted in more frequent and shorter feeding forays and less energy expenditure than in heavy fast ice years. This resulted in a substantially higher breeding success. There was a strong correspondence between high breeding success and high positive SAM Index values, i.e. in 1993, 1998 and 1999. This suggests that the SAM may underpin interannual variability in fast ice distribution and emperor penguin breeding success at Pointe Géologie. More work is required, however, to better understand the exact nature of the impact of different phases of SAM and El Niño-Southern Oscillation teleconnections on fast ice behaviour and, ipso facto, penguin breeding success and demographics.

An intriguing glimpse of conditions in the winter of 1963 suggests that substantially less fast ice was present than in 1992 to 1999 . The highly successful breeding season in 1963 appears to be related to meteorological conditions significantly different from those in the 1990 s, i.e. a large number of strong wind events from a more southerly direction. This is in distinct contrast to current meteorological conditions in the region.

Given the geographically isolated nature of the Pointe Géologie colony and its unusual and unique physical setting, the conclusions presented are specific to this particular colony and may be representative of other colonies in a limited way only. Among local factors, another possible influence on the population dynamics of this colony is the retreat of the Astrolabe Glacier tongue, which lies immediately adjacent to the colony and may afford protection from storms and fast ice break-up events (Jouventin et al. 1984). Although the glacier has retreated in recent years (Frezzotti \& Polizzi 2002), the exact nature and impact of such change on the penguins is unknown. Future modelling of population dynamics should take this factor into account, i.e. local as well as large-scale physical processes should be assessed, should appropriate data on the glacier tongue become available.

On decadal and longer time scales, changes in fast ice distribution are also likely to occur in response to changes in the distribution of grounded icebergs (Frezzotti \& Polizzi 2002, Massom 2003) as well as wind regimes via their impact on fast ice distribution. It follows that any variability in iceberg discharge rates, not only from local glaciers but also those upstream in the East Wind Drift, will potentially affect emperor penguin breeding success at Pointe Géologie.

Although this study has focussed largely on the impact of fast ice, many complex and poorly understood environmental processes and interactions likely affect emperor penguin breeding success and demographics (Ainley et al. 2005). More work is required, for example, to determine how changes in sea ice distribution (both pack and fast ice) affect prey availability and predator-prey interactions - to follow up on the hypothesis of Barbraud \& Weimerskirch (2001) that largescale reduction in pack ice extent may reduce food availability, negatively impacting penguin adult survival. Only then can a more coherent model be constructed that will better explain the observations and response of emperor penguins to environmental variability and/or change (Croxall et al. 2002). Based upon the findings presented here, this model should include fast ice. 
Acknowledgements. Sincere thanks are extended to: S. Pendlebury and Australian Bureau of Meteorology staff for Casey AVHRR data; R. Porter-Smith (CSIRO Marine and Atmospheric Research, Australia) for providing bathymetric data; B. Giles (Australian Antarctic Division [AAD]) for information on grounded versus drifting icebergs and help with Fig. 3; D. Lubin and the Arctic and Antarctic Research Center, Scripps Institution of Oceanography for AVHRR and DMSP OLS data/processing; P. Virtue and K. Michael (IASOS, University of Tasmania) and B. Wienecke and G. Robertson (AAD) for their helpful comments; and B. Murphy (Australian Bureau of Meteorology) for information on the station meteorological data. The review comments of K. Reid (CCAMLR) and 2 anonymous reviewers greatly improved the paper. SSM/I sea ice concentration data were obtained from the NASA Earth Observing System Distributed Active Archive Center at the U.S. National Snow and Ice Data Center, University of Colorado, Boulder (available at: www.nsidc.org). Radarsat SAR data (courtesy of the Canadian Space Agency and Radarsat International) were obtained from NASA grant NRA-99-OES-10, and processed by the Alaska Satellite Facility (Fairbanks, Alaska). Meteorological data for Dumont d'Urville were obtained from the SCAR READER project (available at: www.antarctica.ac.uk/met/READER/). SAM index data were obtained from G. Marshall (BAS) at: www.nerc-bas.ac.uk/icd/gjma/sam.html, and SOI data from the Australian Bureau of Meteorology (available at: www. bom.gov.au/climate/current/soihtm1.shtml). Thanks are also due to P. Reid (BoM and ACE CRC) for help with the SOI data. The Australian Antarctic Territory coastline data come from the Australian Antarctic Data Centre. Argon satellite imagery was obtained from the USGS EROS Data Center at: http:// edcsns17.cr.usgs.gov/EarthExplorer/. This work was supported by the Australian Government's Cooperative Research Centre programme through the Antarctic Climate and Ecosystems Cooperative Research Centre, and contributes to Australian Antarctic Science Project 3024.

\section{LITERATURE CITED}

Ainley DG (1983) Biomass of birds and mammals in the Ross Sea. In: Siegfried, WR, Condy, PR, Laws RM (eds) Antarctic nutrient cycles and food webs. Springer-Verlag, Berlin, p 498-515

Ainley DG, Clarke ED, Arrigo K, Fraser WR, Kato A, Barton KJ, Wilson PR (2005) Decadal-scale changes in the climate and biota of the biota of the Pacific sector of the Southern Ocean. Antarct Sci 17:171-182

Ancel A, Kooyman GL, Ponganis PJ, Gendner JP and others (1992) Emperor penguins foraging behaviour as a resource detector in winter and summer. Nature 360: $336-339$

Arrigo KR, Kremer JN, Sullivan CW (1993) A simulated Antarctic fast-ice ecosystem. J Geophys Res 98:6929-6946

Barber-Meyer, SM, Kooyman, GL, Ponganis, PJ (2008) Trends in western Ross Sea emperor penguin chick abundances and their relationships to climate. Antarct Sci doi: 10.1017/S0954102007000673: 1-9

Barbraud C, Weimerskirch H (2001) Emperor penguins and climate change. Nature 411:183-186

Cherel Y, Kooyman GL (1998) Food of emperor penguins (Aptenodytes forsteri) in the western Ross Sea, Antarctica. Mar Biol 130:335-344

Comiso JC (1995) SSM/I concentrations using the Bootstrap algorithm. NASA Reference Publication 1380. NASA, Washington, DC
Comiso JC (2002) Bootstrap sea ice concentrations from Nimbus-7 SMMR and DMSP SSM/I. National Snow and Ice Data Center, Boulder, CO

Cracknell AP (1997) The advanced very high resolution radiometer. Taylor \& Francis, Philadelphia, PA

Crocker GB, Wadhams P (1989) Breakup of Antarctic fast ice. Cold Reg Sci Technol 17:61-76

Croxall JP, Trathan PN, Murphy EJ (2002) Environmental change and Antarctic seabird populations. Science 297: 1510-1514

Enomoto H, Nishio F, Warashina H, Ushio S (2002) Satellite observation of melting and break-up of fast ice in LützowHolm Bay, East Antarctica. Polar Met Glaciol 16:1-14

Fedotov VI, Cherapanov NV, Tyshko KP (1998) Some features of the growth, structure and metamorphism of East Antarctic landfast sea ice. In: Jeffries, MO (ed) Antarctic sea ice physical processes, interactions and variability. Antarctic Research Series 74. American Geophysical Union, Washington, DC, p 343-354

> Frezzotti M, Polizzi M (2002) 50 years of ice-front changes between the Adélie and Banzare Coasts, East Antarctica. Ann Glaciol 34:235-240

Garrison DL (1991) Antarctic sea ice biota. Am Zool 31:17-33

Giles AB, Massom RA, Lytle VI (2008) Fast ice distribution in East Antarctica during 1997 and 1999 determined using Radarsat data. J Geophys Res 113:C02S14. doi:10.1029/ 2007JC004139

Gloersen P, Campbell WJ, Cavalieri DJ, Comiso JC, Parkinson CL, Zwally HJ (1992) Arctic and Antarctic sea ice, 1978-1987: satellite passive-microwave observations and analysis. NASA Special Publication SP-511, Washington, DC

Gonzalez RC, Woods RE (1992) Digital image processing. Addison-Wesley, Reading, MA

Groscolas R (1988) The use of body mass loss to estimate metabolic rate in fasting sea birds: a critical examination based on emperor penguins (Aptenodytes forsteri). Comp Biochem Physiol A 90:361-366

- Hall A, Visbeck M (2002) Synchronous variability in the Southern Hemisphere atmosphere, sea ice, and ocean resulting from the Annular Mode. J Clim 15:3043-3057

Heil, P (2006) Atmospheric conditions and fast ice at Davis Station, East Antarctica: a case study. J Geophys Res 111:C05009, doi:10.1029/2005JC002904

Hill K (2000) AVHRR processing system. Antarctic CRC Research Report 16, Hobart

Jenouvrier S, Barbraud C, Cazelles B, Weimerskirch H (2005a) Modelling population dynamics of seabirds: importance of the effects of climate fluctuations on breeding proportions. Oikos 108:511-522

Jenouvrier S, Barbraud C, Weimerskirch H (2005b) Longterm contrasted responses to climate of two Antarctic seabird species. Ecology 86:2889-2903

Jouventin P, Stahl JC, Weimerskirch H, Mougin JL (1984) The seabirds of the French sub-Antarctic islands and Adélie Land, their status and conservation. In: Croxall, JP, Evans, PGH, Schreiber, RW (eds) Status and conservation of the world's seabirds. ICBP Technical Publication No. 2. International Council for Bird Preservation, Cambridge, p 609-625

> Jouventin P, Barbraud C, Rubin M (1995) Adoption in the emperor penguin, Aptenodytes forsteri. Anim Behav 50: 1023-1029

Key J (2002) The cloud and surface parameter retrieval (CASPR) system for polar AVHRR user's guide. Cooperative Institute for Meteorological Satellite Studies, University of Wisconsin, Madison, WI 
Kidwell KB (1997) NOAA polar orbiter data users guide (TIROS-N, NOAA-6, NOAA-7, NOAA-8, NOAA-9, NOAA10, NOAA-11, NOAA-12, NOAA-13, and NOAA-14). US Department of Commerce, NOAA, NESDIS, National Climatic Data Center, Climate Services Division, Satellite Services Branch, Suitland, MD

Kirkwood R, Robertson G (1997a) Seasonal change in the foraging ecology of emperor penguins on the Mawson Coast, Antarctica. Mar Ecol Prog Ser 156:205-223

Kirkwood R, Robertson G (1997b) The foraging ecology of female emperor penguins in winter. Ecol Monogr 67: 155-176

Kooyman GL (1993) Breeding habitats of emperor penguins in the western Ross Sea. Antarct Sci 5:143-148

Kooyman GL, Burns J (1999) Weddell seal versus emperor penguin: boss of the Ross Sea. Am Zool 39:9-19

Kooyman GL, Hunke EC, Ackley SF, van Dam RP, Robertson G (2000) Moult of the emperor penguin: travel, location, and habitat selection. Mar Ecol Prog Ser 204:269-277

Kozlovsky AM, Nazintsev YL, Fedotov VI, Cherapanov NV (1977) Fast ice of the Eastern Antarctic (in Russian). Proc Sov Antarct Exped 63:1-129

Kwok R, Comiso JC (2002) Southern Ocean climate and sea ice anomalies associated with the Southern Oscillation. J Clim 15:487-501

Langhorne PJ, Squire VA, Fox C, Haskell TG (2001) Lifetime estimation for a land-fast ice sheet subjected to ocean swell. Ann Glaciol 33:333-338

Lefebvre W, Goosse H, Timmermann R, Fichefet T (2004) Influence of the Southern Annular Mode on the sea iceocean system. J Geophys Res 109:C09005. doi:10.1029/ 2004JC002403

Liu J, Curry JA, Martinson DG (2004) Interpretation of recent Antarctic sea ice variability. Geophys Res Lett 31:L02205. doi:10.1029/2003GL018732

Lorenzin GM (2000) Australian Antarctic Territory coastline, Australian Antarctic Data Centre-SnoWhite Metadata (available at: http://data.aad.gov.au). Australian Antarctic Division, Kingston

Lubin D, Massom RA (2006). Polar remote sensing, Vol 1. Atmosphere and polar oceans. Praxis/Springer, Chichester \& Berlin

Marshall GJ (2003) Trends in the Southern Annular Mode from observations and reanalyses. J Clim 16:4134-4143

Massom RA (2003) Recent iceberg calving events in the Ninnis Glacier region, East Antarctica. Antarct Sci 15: 303-313

> Massom RA, Hill K, Lytle VI, Worby A, Allison I (2001) Effects of regional fast-ice and iceberg distributions on the behaviour of the Mertz Glacier Polynya, East Antarctica. Ann Glaciol 33:391-398

McMinn A, Ashworth C, Ryan KG (2000) In situ primary production of an Antarctic fast ice bottom algal community. Aquat Microb Ecol 21:177-185

Micol T, Jouventin P (2001) Long-term population trends in seven Antarctic seabirds at Pointe Géologie (Terre Adélie): human impact compared with environmental change. Polar Biol 24:175-185

Murphy BF, Pettré P (1995) Observed changes in the interannual variability and the annual cycle at Antarctic coastal stations. Note de Centre 45, Météo-France, CNRM, Toulouse

Murphy EJ, Clarke A, Symon C, Priddle J (1995) Temporal variation in Antarctic sea-ice: analysis of a long term fastice record from the South Orkney Islands. Deep-Sea Res I
42:1045-1062

Orsi AH, Whitworth T III, Nowlin WD Jr (1995) On the meridional extent and fronts of the Antarctic Circumpolar Current. Deep-Sea Res 42:641-673

Panofsky HA, Brier WG (1965) Some applications of statistics to meteorology. Pennsylvania State University, Philadelphia, PA

Periard C, Pettré P (1993) Some aspects of the climatology of Dumont d'Urville, Adélie Land, Antarctica. Int J Climatol 13:313-327

> Porter-Smith R (2003) Bathymetry of the George Vth Land shelf and slope. Deep-Sea Res II 50:1337-1341

Prévost J (1961) Ecologie du manchot empereur. Expéditions Polaires Françaises. Hermann Press, Paris

Robertson GG (1994) The foraging ecology of Emperor penguins (Aptenodytes forsteri) at two Mawson Coast colonies, Antarctica. PhD Thesis, University of Tasmania, Hobart

> Rodary D, Bonneau W, Le Maho Y, Bost CA (2000) Benthic diving in male emperor penguins Aptenodytes forsteri foraging in winter. Mar Ecol Prog Ser 207:171-181

Satoh H, Watanabe K (1988) Primary productivity in the fast ice area near Syowa station, Antarctica, during spring and summer 1983/84. J Oceanogr 44:287-292

Seaman R, Bourke W, Steinle P, Hart T, Embery G, Naughton M, Rikus L (1995) Evolution of the Bureau of Meteorology's Global Assimilation and Prediction System Part 1. Analysis and initialisation. Austr Met Mag 44:1-18

Simmonds I, King JC (2004) Global and hemispheric climate variations affecting the Southern Ocean. Antarct Sci 16: 401-413

> Stammerjohn SE, Martinson DG, Smith RC, Yuan X, Rind D (2008) Trends in Antarctic annual sea ice retreat and advance and their relation to ENSO and Southern Annular Mode Variability. J Geophys Res 113:C03S90. doi: 10.1029/2007JC004269

Thomas DP, DeMaster DP (1983) Parameters affecting survival of Weddell seal pups (Leptonychotes weddelli) to weaning. Can J Zool 61:2078-2083

Ushio S (2006) Factors affecting fast-ice breakup frequency in Lützow-Holmbukta, Antarctica. Ann Glaciol 44:177-182

Weimerskirch H, Inchausti P, Guinet C, Barbraud C (2003) Trends in bird and seal populations as indicators of a system shift in the Southern Ocean. Antarct Sci 15:249-256

- Wienecke BC, Robertson G (1997) Foraging space of emperor penguins Aptenodytes forsteri in Antarctic shelf water in winter. Mar Ecol Prog Ser 159:249-263

Williams RN, Michael KJ, Pendlebury S, Crowther P (2002) An automated image analysis system for determining seaice concentration and cloud cover from AVHRR images of the Antarctic. Int J Remote Sens 23:611-625

Willis CJ, Macklin JT, Partington KC, Teleki KA, Rees WG, Williams RG (1996) Iceberg detection using ERS-1 synthetic aperture radar. Int J Remote Sens 17:1777-1795

WMO (World Meteorological Organization) (1970) The WMO sea-ice nomenclature. Terminology, codes and illustrated glossary. WMO/OMM/BMO 259, TP 145. World Meteorological Organization, Geneva

Yamanouchi T, Seko K (1992) Antarctica from NOAA satellites, clouds, ice and snow. National Institute of Polar Research, Tokyo

Zimmer I, Wilson RP, Gilbert C, Beaulieu M, Ancel A, Plötz J (2007) Foraging movements of emperor penguins at Pointe Géologie, Antarctica. Polar Biol 31:229-243 doi:10.1007/ s00300-007-0352-5

Submitted: March 28, 2008; Accepted: September 11, 2008

Proofs received from author(s): December 16, 2008
Editorial responsibility: Andrew Brierley, St. Andrews, UK 